\title{
EFFECT OF INOSINE ON THE POST-TRANSFUSION SURVIVAL OF STORED RABBIT ERYTHROCYTES *
}

\author{
By A. WILLIAM SHAFER AND GRANT R. BARTLETT
}

(From the Scripps Clinic and Research Foundation, La Jolla, Calif.)

(Submitted for publication June 8, 1959; accepted September 10, 1959)

In 1955 Gabrio, Donohue, Huennekins and Finch (1) reported that inosine prolonged the period that human blood could be stored at $4^{\circ} \mathrm{C}$. in acid citrate dextrose (ACD); their experimental evidence indicated greater than 70 per cent viability of the erythrocytes after six weeks of storage. Because of these encouraging findings, a cooperative study was undertaken in which the posttransfusion survival of erythrocytes from blood stored in ACD and in ACD plus inosine (ACDI) was compared (2). Results of this study were not as encouraging as those previously found, and it was reported that only four of the 23 units of blood stored for six weeks in ACDI had better than 70 per cent post-transfusion survival of the erythrocytes. Because of these rather inconsistent results the present study was instituted to learn more about factors which might influence the effect of inosine on the stored erythrocyte. To facilitate a large number and variety of tests, rabbit blood was used since previous work indicated that the results probably would be applicable to human blood.

\section{METHODS}

Blood was drawn from one or two female New Zealand rabbits (depending on the quantity of blood to be stored) by intracardiac puncture with heparinized syringes, added to $A C D$, transferred to siliconized flasks in 5 or $10 \mathrm{ml}$. volumes, and stored for six weeks at $4^{\circ} \mathrm{C}$. Sterile precautions were observed throughout the storage period. Inosine was autoclaved in normal saline unless otherwise stated. In each experiment, ACD blood was stored without inosine as a control and with inosine under various experimental circumstances. At the end of the storage period, post-transfusion survival of the erythrocytes was determined by the double isotope $\left(\mathrm{Cr}^{\mathrm{s1}}\right.$ and $\left.\mathrm{P}^{\mathrm{*}}\right)$ method as described by Gibson and Scheitlin (3). A separate female New Zealand rabbit was used for each post-transfusion survival study.

* Supported in part by the U. S. Army Medical Research and Development Command, Office of the Surgeon General.

\section{RESULTS}

Tables I through IV give the 24 hour posttransfusion survival results for erythrocytes of the blood stored six weeks at $4^{\circ} \mathrm{C}$. in ACD alone (Table I), and in ACD supplemented with inosine (Tables II through IV).

Fifteen control blood samples stored in ACD alone gave erythrocyte post-transfusion survival values ranging from 4 to 33 per cent with a mean of 18 per cent and a standard deviation of 7.5. Post-transfusion survival of erythrocytes from 49 samples of blood stored in ACDI varied from 28 to 100 per cent with a mean of 61 per cent and a standard deviation of 22 . Thus, on the average,

TABLE I

Twenty-four hour post-transfusion survival of erythrocytes stored six weeks at $4^{\circ} \mathrm{C}$. in acid citrate dextrose $(A C D)$

\begin{tabular}{cccc}
\hline Sample & $\begin{array}{c}\text { \% 24 Hr. } \\
\text { post-transfusion } \\
\text { survival }\end{array}$ & Sample & $\begin{array}{c}\text { \% 24 Hr. } \\
\text { post-transfusion } \\
\text { survival }\end{array}$ \\
\hline 1 & 9 & 9 & 23 \\
2 & 20 & 10 & 25 \\
3 & 12 & 11 & 33 \\
4 & 12 & 12 & 17 \\
5 & 11 & 13 & 23 \\
6 & 17 & 14 & 25 \\
7 & 20 & 15 & 27 \\
8 & 4 & Mean & 18 \\
& & Standard deviation & \pm 7.5 \\
\hline
\end{tabular}

TABLE II

Effect of inosine* on blood stored six weeks at $4^{\circ} C$. in $A C D$; variation of amount and of time of addition of inosine

\begin{tabular}{ccc}
\hline $\begin{array}{c}\text { Inosine } \\
\text { mg./ml. } \\
\text { ACD-blood }\end{array}$ & $\begin{array}{c}\text { Time of } \\
\text { addition }\end{array}$ & $\begin{array}{c}\text { \% 24 Hr. } \\
\text { post-trans- } \\
\text { fusion survival }\end{array}$ \\
\hline 4.0 & 0 day & 65 \\
4.0 & 0 day & 73 \\
4.0 & 0 day & 93 \\
4.0 & 21 days & 55 \\
4.0 & 21 days & 87 \\
2.0 & 0 day & 72 \\
0.4 & Semiweekly & 100 \\
0.2 & Semiweekly & 59 \\
\hline
\end{tabular}

* Schwarz Laboratories, Inc., Lot No. 5504. 


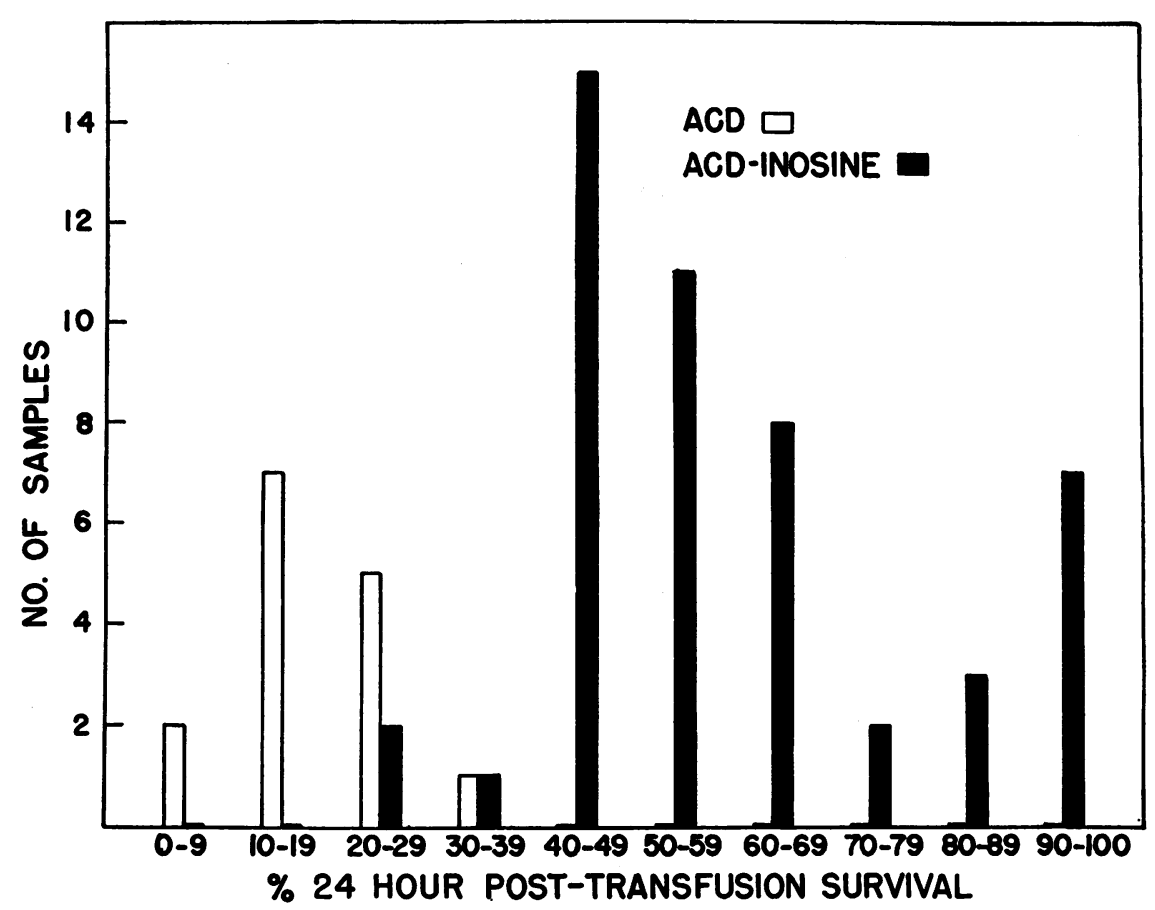

Fig. 1. Incidence Graph of 24 Hour Post-Transfusion Survival of Erythrocytes Stored for Six Weeks at $4^{\circ} \mathrm{C}$. in Acid Citrate Dextrose (ACD) and in ACD-INOSINE

Mean 24 hour post-transfusion survival of erythrocytes from 15 samples of blood stored in ACD was 18 per cent \pm 7.5 , and from 49 samples of blood stored in ACDinosine was 61 per cent \pm 22 .

3.4 times as many erythrocytes were viable after six weeks of storage when ACD was supplemented with inosine. The results are shown graphically in Figure 1.

The post-transfusion survival of erythrocytes from several samples of stored blood was followed past 24 hours and the curves, presented in Figure 2 , show, in agreement with other investi-

TABLE III

Effect of inosine* on blood stored six weeks at $4^{\circ} \mathrm{C}$. in $A C D$; variation in autoclaving and formula of $A C D$

\begin{tabular}{cclc}
\hline \hline $\begin{array}{c}\text { Inosine } \\
\text { mg./ml. } \\
\text { ACD-blood }\end{array}$ & $\begin{array}{c}\text { ACD } \\
\text { formula }\end{array}$ & $\begin{array}{c}\text { Inosine solution } \\
\text { autoclaved }\end{array}$ & $\begin{array}{c}\% 24 \mathrm{Hr} . \\
\text { post-transfusion } \\
\text { survival }\end{array}$ \\
\hline 4.0 & B & Normal saline & 52 \\
4.0 & B & Normal saline & 69 \\
4.0 & B & ACD & 52 \\
4.0 & B & ACD & 66 \\
4.0 & A & Normal saline & 35 \\
4.0 & A & Normal saline & 81 \\
4.0 & A & ACD & 53 \\
4.0 & A & ACD & 69 \\
\hline
\end{tabular}

* Schwarz Laboratories, Inc., Lot No. 5504. gators, that nonviable cells are rapidly removed from the circulation, and that those remaining after 24 hours disappear at approximately a normal rate.

The following variables were investigated: 1 ) addition of inosine at various times during the storage period, 2) periodic shaking of the blood, 3) autoclaving inosine in ACD or in normal saline, and 4) addition of different lots of inosine manufactured by several suppliers. There were no clear-cut differences which would allow the conclusion that any of these factors significantly influenced erythrocyte viability during storage.

Samples of inosine were examined on columns of Dowex-1 formate after autoclaving in ACD or in normal saline. In both cases the compound was eluted quantitatively as a sharp band in the position expected, analyzed correctly by ultraviolet absorption and the orcinol method, and therefore showed no evidence that any breakdown of the nucleoside was produced. 
TABLE IV

Effect of inosine (4 mg. per ml. ACD-blood) on blood stored six weeks at $4^{\circ} \mathrm{C}$. in ACD; variation of inosine preparation

\begin{tabular}{lllc}
\hline \hline $\begin{array}{c}\text { Inosine } \\
\text { preparation }\end{array}$ & $\begin{array}{c}\% \text { 24 Hr. } \\
\text { post-trans- } \\
\text { fusion survival }\end{array}$ & $\begin{array}{c}\text { Inosine } \\
\text { preparation }\end{array}$ & $\begin{array}{c}\text { \% 24 Hr. } \\
\text { post-trans- } \\
\text { fusion survival }\end{array}$ \\
\hline S-5705* & 44 & S-5504 & 66 \\
S-5705 & 49 & S-5504 & 60 \\
S-5601 & 40 & S-5504 & 65 \\
S-5601 & 51 & S-5706 & 49 \\
S-5602 & 40 & S-5706 & 65 \\
S-5602 & 57 & S-5706 & 48 \\
S-5605 & 40 & S-5706 & 51 \\
S-5605 & 46 & S-Crude† & 41 \\
S-5606 & 43 & S-Crude & 84 \\
S-5606 & 58 & S-Crude & 95 \\
S-5702 & 28 & S-Crude & 97 \\
S-5702 & 56 & P-5706ł & 100 \\
S-5703 & 40 & P-5706 & 92 \\
S-5703 & 49 & P-2303 & 100 \\
S-5704 & 40 & P-2303 & 29 \\
S-5504 & 48 & C-100898§ & 40 \\
& & C-100898 & 52 \\
\hline
\end{tabular}

* Schwarz Laboratories, Inc. tion.

$\ddagger$ Pabst Laboratories.

$\$$ California Corporation.

\section{DISCUSSION}

The results are distinguished by a marked variability in the survival of the erythrocytes stored in ACD either with or without inosine. It is not possible to ascertain from these experiments how much of the variation was due to the blood itself and how much to some influence of the experimental manipulations. It will be difficult to assess any of these inconstant effects of inosine or other changes in incubation solution or technic without more information about erythrocyte viability after extended storage periods in ACD alone.

It is obvious, nevertheless, that inosine has a favorable influence on the survival of the rabbit erythrocyte when stored in ACD, and it is felt that further investigation of the effect of various nucleosides on stored blood is warranted.

\section{SUM MARY}

Twenty-four hour post-transfusion survival of erythrocytes was determined on 64 samples of

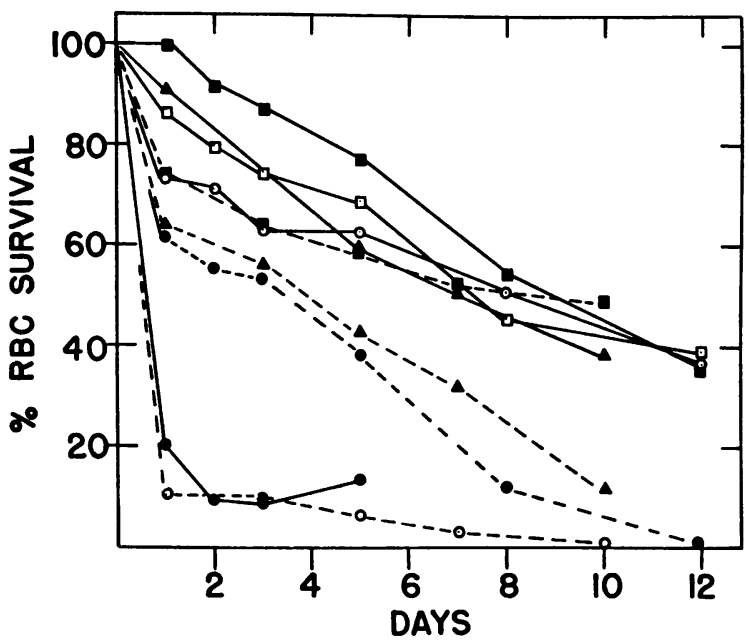

Fig. 2. Post-Transfusion Survival of ErythroCytes Stored Six WeEks in ACD and in ACD-InoSINE ( $\mathrm{CR}^{\mathrm{B1}}$ AND $\mathrm{P}^{32}$ Method)

Graphic representation of per cent survival of calculated erythrocytes transfused, $\mathrm{O}-\ldots, \mathrm{O}^{-}$and - control blood samples stored in ACD. Others, blood samples stored in ACD-inosine.

blood stored for six weeks at $4^{\circ} \mathrm{C}$. in acid citrate dextrose (ACD) or in ACD plus inosine (ACDI). Erythrocyte post-transfusion survival values of 4 to 33 per cent and 28 to 100 per cent for blood stored in ACD and in ACDI, respectively, were obtained.

Inosine has a beneficial effect on the viability of stored blood although there is considerable variability in this effect.

\section{REFERENCES}

1. Gabrio, B. W., Donohue, D. M., Huennekens, F. M., and Finch, C. A. Erythrocyte preservation. VII. Acid-citrate-dextrose-inosine (ACDI) as a preservative for blood during storage at $4^{\circ} \mathrm{C}$. J. clin. Invest. 1956, 35, 657.

2. Lange, R. D., Crosby, W. H., Donohue, D. M., Finch, C. A., Gibson, J. G., II., McManus, T. J., and Strumia, M. M. Effect of inosine on red cell preservation. J. clin. Invest. 1958, 37, 1485.

3. Gibson, J. G., II, and Scheitlin, W. A. A method employing radioactive chromium for assaying the viability of human erythrocytes returned to circulation after refrigerated storage. J. Lab. clin. Med. 1955, 46, 679. 